\title{
Remote Sensing GIS Based Spatio-temporal Land Use/ Cover Study of Western Ethiopian Highlands -A Case of Jima Arjo District
}

\author{
Muleta Ebissa Feyissa* \\ Department of Earth Science, College of Computational and Natural Sciences, Wollega University, \\ P.O Box: 395, Nekemte, Ethiopia
}

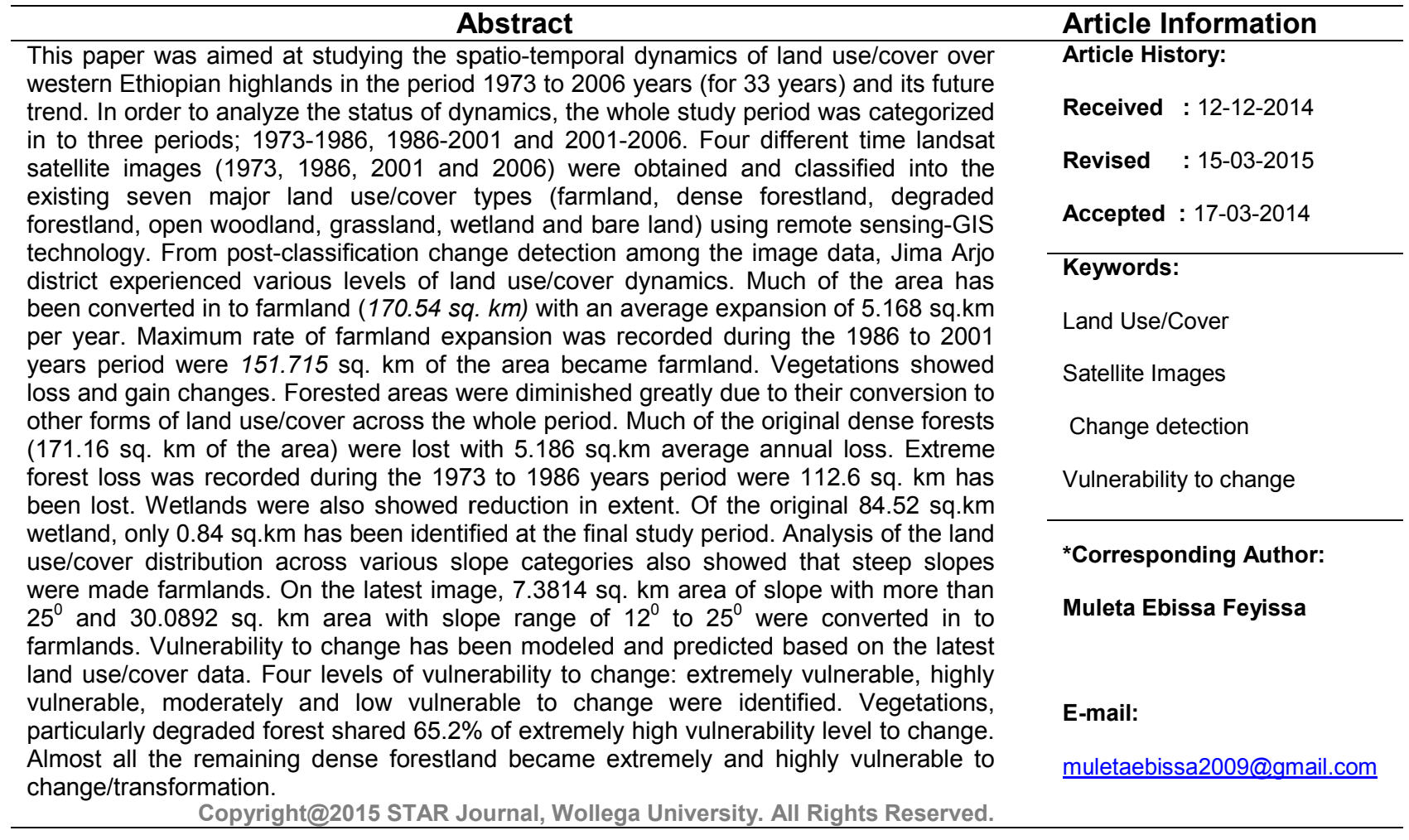

\section{INTRODUCTION}

Land use and land cover are not equivalent but they are connected and function as hybrids. While land use is the human employment of the land, land cover indicates the physical state of land. The change of human use of land is associated with change in the physical states of land cover. Although land use/cover change are caused by both natural and anthropogenic factors, most land use/cover changes and dynamics are attributed to the interaction between human continued demand for land products and the capacity of the land and the environment to sustain the demand (Meyer and Turner, 1998).

Many research studies indicated that land use/cover dynamism is primarily associated with agricultural activity. Wright (1993), Botkin and Keller (2005) described that agriculture and settlements are the major ways in which people have changed the natural landscape. Three most important human factors were recognized as change agents of land use/cover. The first is the need to provide food for rapidly growing population. This necessitates the expansion and intensification of agricultural land. The second is the provision of land for the landless in order of self sufficiency to exist and the third is to provide land for multinational companies to carry out agribusinesses.

Ethiopia is an agrarian country where agriculture provides a livelihood for over $90 \%$ of its population (Ministry of Agriculture \& Rural Development, et al., 2005). At the inception of agriculture, most of the land cover of the country was believed to have been forest and at the turn of $20^{\text {th }}$ century, $40 \%$ of the country's land surface had been covered with forest. Since then, forest clearance was started in favor of crop production (Solomon Abate, 1994). With the rapid growing population 


\section{Muleta Ebissa Feyissa}

of the country, the event yet calls for more forest clearance for further farm expansion, grazing and extraction of forest and forest products (Krauer, 1988).

The highlands of the country are favorable for human habitat and they are the most significant economic areas. But they have signified rugged topography dissected by deep gorges with slopes associated with diverse climate (Hurni, 1986). Such physiographic features require careful agro-ecologically sustainable management (World Bank, 2006).

South western high-lands of Ethiopia; were the study was conducted/Jima Arjo district/, was relatively settled recently, less densely populated and believed to have good vegetation cover (Solomon Abate, 1994). However, the severity and rate of loss of natural vegetation in the region currently is indeed alarming. This can be realized from the work of Taffa Tulu (2002) in that the forest resources of Ethiopia are concentrated on $3 \%$ of the area mainly located in the south western highlands.

Proper organization and monitoring of land resources requires not only an understanding of the spatial and temporal patterns of resources but also insight in to the spatial and temporal process governing their availability. Such analysis demand timely repetitive and continuous
Sci. Technol. Arts Res. J., Jan-March 2015, 4(1): 139-148

spatial data. Remote sensing and GIS technique has proven capacity in assessing and monitoring the land resource.GIS, using multi criteria analytical facilities can integrate multi-criterion comparison techniques so as to predict geographical related problems (Eastman, 2006).

Towards this a study has been conducted to assess the status and trend of land use/cover. The study delineated change and degradation vulnerable areas in the district using remote sensing and GIS technology.

\section{MATERIALS AND METHODS}

\section{Background of the Study Area Location and Physiography}

Jima Arjo is found in East Wollega Zone of Oromia region right at $379 \mathrm{Km}$ West of Addis Ababa. The district is located in between $8^{0} 33^{\prime}$ to $8^{0} 55^{\prime} \mathrm{N}$ latitudes and $36^{\circ} 22^{\prime}$ to $36^{0} 44^{\prime} \mathrm{E}$ longitudes (figure 1 ).

The physical landscape of Jima Arjo is quite diversified. The major topographic features of the area are composed of hilly, flat to undulating rugged topography, plain, plateau and valley with altitude variation from 1264 at Didessa valley floor in the south west to $2599 \mathrm{~m}$ a.s.l. at Hine ridge in the North western part of the area.

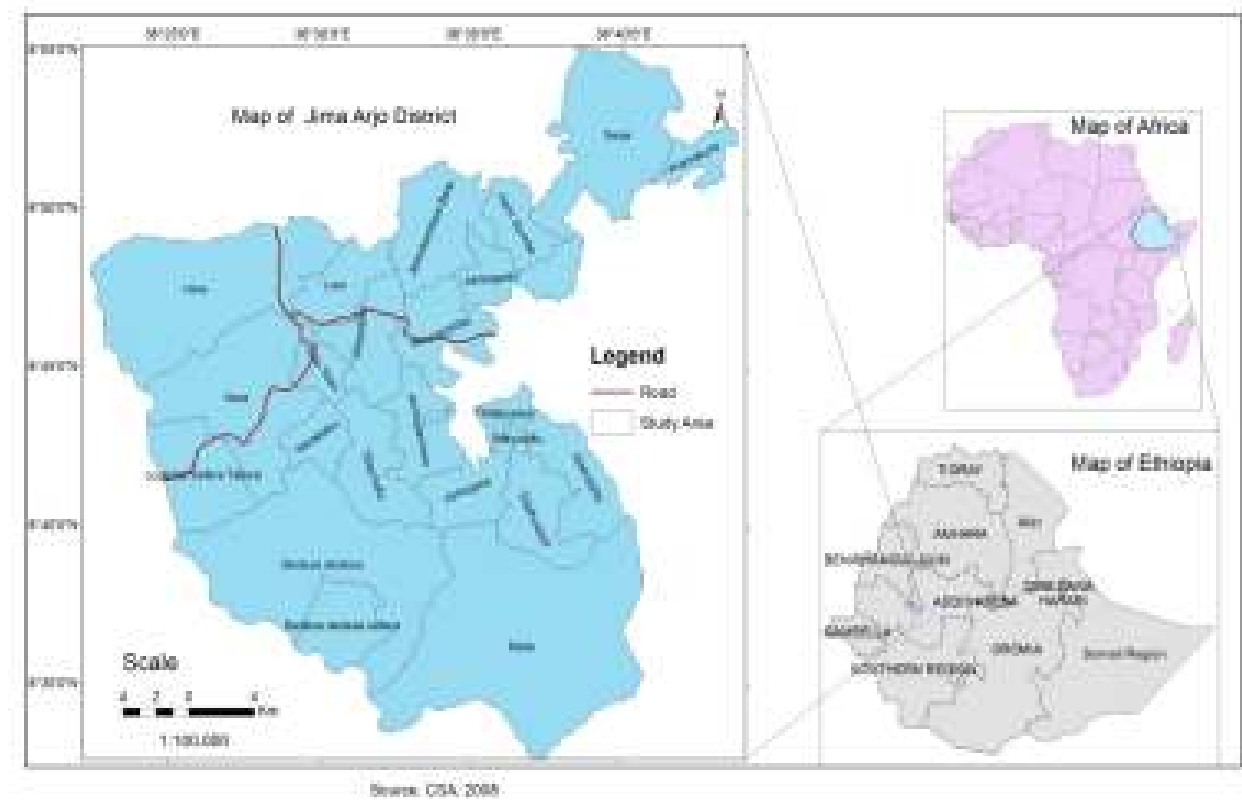

Figure 1: Map of the study area

\section{Climate}

According to the agro-climatic classification of Ethiopia by Ministry of Agriculture, Rurl Development of Ethiopia, Regional Land Management and World Agro forestry Center (2005), $30 \%$ of the area has lowlands with an elevation of $<1500 \mathrm{~m}$ a.s.l, $58 \%$ of it has mid altitude with elevation between $1500-2300 \mathrm{~m}$ a.s.l and $12 \%$ of it is highland having elevation $>2300 \mathrm{~m}$ a.s.l.

The mean rainfall based on 19 years record (19882006 ) is $1855.3 \mathrm{~mm}$. Even though the intensity of rain varies, almost all months receive rainfall. April-September are months with high rainfall and over $76 \%$ of the area receives maximum rain from May to September. The lowest mean monthly rainfall $(14.1 \mathrm{~mm})$ was recorded in the month of January while the highest $332 \mathrm{~mm}$ recorded in August.
The recorded temperature of the study area ranges from $10^{\circ} \mathrm{C}$ to $23^{\circ} \mathrm{C}$ with average annual temperature of $\sim 16^{\circ} \mathrm{C}$. The hottest and coldest months are March and July, respectively.

\section{Description of Data Used}

The study requires ground surveying of land resources data which is often expensive. Such data analysis also demands timely repetitive and continuous spatial data (Wall et al., 1982). Remote sensing and GIS technology has proven capability in acquiring and processing such data. LandSat satellite remote sensing employing multispectral scanning systems provide data for the identification of land cover at different times on a continual basis (Lillesand and Kiefer, 2000). 
Remotely sensed LandSat satellite image data of four periods (1973, 1986, 2001 and 2006 years) (table 1), Global digital elevation (SRTM) data, shape file data, digital soil data and toposheets were used for the study. Climate data (RF and Temp) and surveyed field data were also employed for the study.

Table 1: Summary of satellites image data used for the study

\begin{tabular}{lccc}
\hline \multicolumn{1}{c}{ Image } & Path/Row & Acquisition Year & Source \\
\hline Landsat MSS & $182 / 054$ & 1973 & GLCF online portal \\
Landsat TM & $170 / 054$ & 1986 & GLCF online portal \\
Landsat ETM+ & $170 / 054$ & 2001 & GLCF online portal \\
Landsat ETM+ & $170 / 054$ & 2006 & GLCF online portal \\
\hline
\end{tabular}

MSS $=$ Multi Spectral Scanner, TM = Thematic Mapper; ETM+= Enhanced Thematic Mapper Plus

\section{Methodology Description}

GIS analysis techniques were used for the study. Digital LandSat satellite images were extracted and enhanced using radiometric and spectral enhancement techniques, RGB to IHS conversions and color combination of the original image so as to make the image visually interpretable and identify features in the image data. The image data has been analyzed and classified in to different land covers using both ERDAS 2010 and ENVI 4.7 software. The classified data were further analyzed for change detection. Terrain data (elevation and slope) generated from SRTM data were processed after patching for the anomalies using 3DEM visual software and further processed using ArcGIS 10.2 software spatial analyst tools. Change susceptibility factors were generated from secondary topomaps through digitization in the ArcMap ArcGIS.

GIS multicriteria analysis techniques and vulnerability analysis through pair-wise comparison has been employed using IDRISI Selva version 17 software. The parameters were weighted and overlay analysis has been implemented in the ArcGIS 10.2 environment (Figure 2).

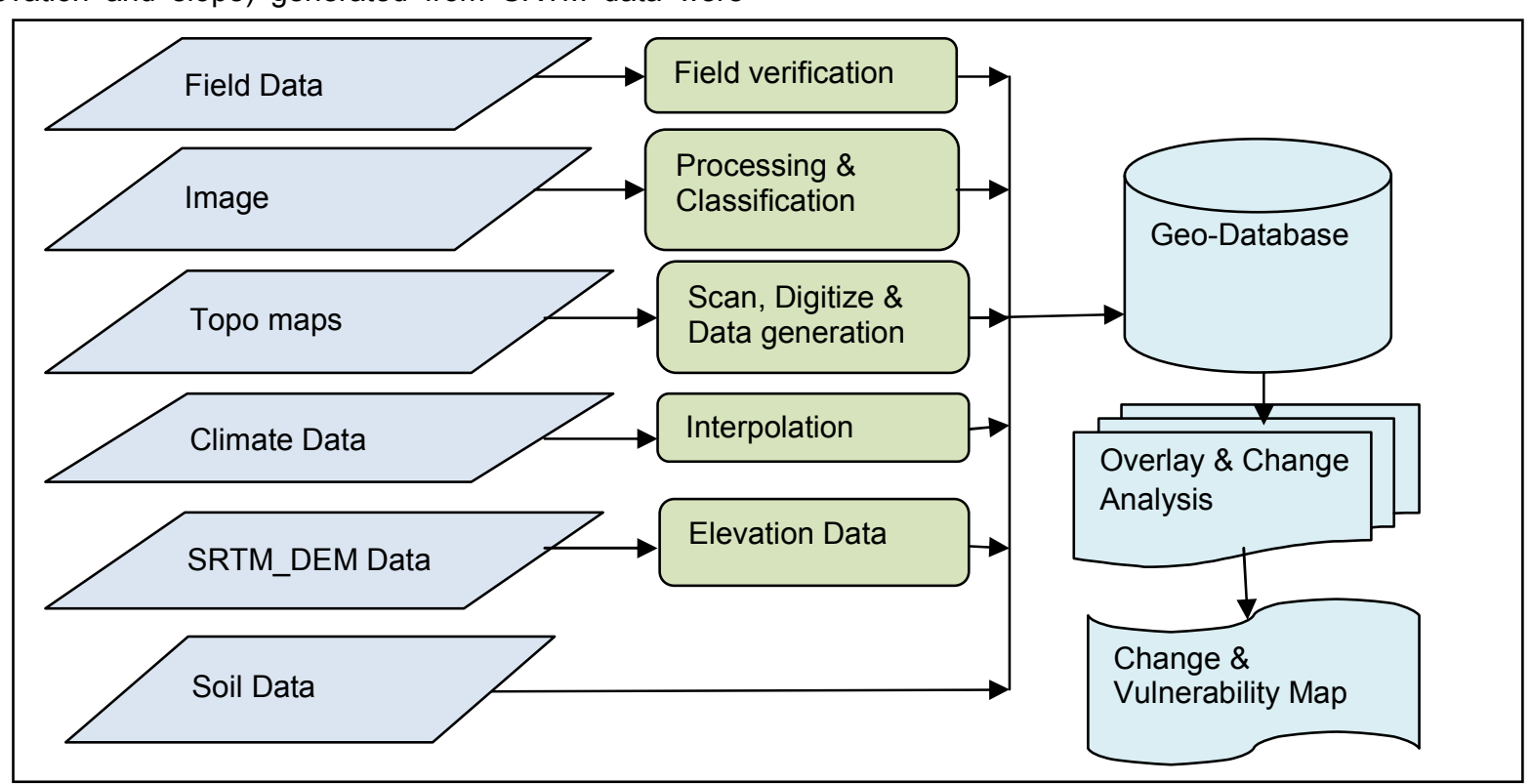

Figure 2: Methodology of the Study

\section{RESULTS AND DESCUSSION}

\section{Satellite Image Processing}

\section{Orthorectification and/or Restoration of the Images}

Image rectification and restoration, which normally precedes any further manipulation (Mather M. Paul, 2004) has been implemented for correcting the distortions introduced to the image data during the acquisition process. The image of the 1986 TM has found with cloud cover since the images were recorded during the summer month over the area. Therefore, some haze compensation techniques were employed on the image. In addition to this, reprojections to Clarke 1880/UTM zone $37 \mathrm{~N}$ were made to all the images since the national map products of Ethiopia use this projection (Bedru Sherefa, 2006).

\section{Image Enhancement and Visual Interpretation}

To aid the visual interpretability and identification of major land use/land cover types of the images histogram equalizer and tasseled cap transformation were employed to the image data. RGB to IHS conversions and color combination of the original image data have also been made. The Vegetation index, NDVI, has also been used to measure the presence and state of vegetation so as to distinguish vegetated areas from others. It was computed from the spectral radiance in $\operatorname{red}(\mathrm{R})$ and near-infrared (NIR) bands (Eq. 1). The value ranges from -1 to 1 , and the highest the value, the proportion of green vegetation in a pixel would be the highest and the lowest negative values are characteristics of either water or bare land (Lillesand et al., 2004). A common range for green vegetation falls between $\approx 0.2$ to 0.8 (ITT, 2006).

$$
N D V I=\frac{N I R-R}{N I R+R}
$$

Different NDVI values were produced following the transformation using the equation. The MSS image 
Muleta Ebissa Feyissa

recorded NDVI values range from about - 0.5 to 0.6 , the TM between $-0.81-0.65$ and that of $\mathrm{ETM}^{+}$falls between 0.9 and 0.64 . These values indicate the state of green vegetation in that the higher the value the higher the amount of healthy green vegetation over the area.

\section{Image Classification and Accuracy Assessment}

The four time period images of the study area were first classified through computer automated unsupervised method in ERDAS IMAGINE 2010 classifier. The image data were classified through supervised technique by combining enhanced visually interpretable data, field
Sci. Technol. Arts Res. J., Jan-March 2015, 4(1): 139-148

(GPS) data, spectral profile and the unsupervised classification. Accordingly, 7(seven) major land use/land covers classes namely: farm land, dense forest, degraded forest, open woodland, grassland; wetland and bare land were identified from the images (Figure 3 ).

After classification the accuracy of the classified data has been assessed using a confusion matrix. Accordingly, the classified image data of 2006 has an overall accuracy of $85 \%$ with kappa statistics of 0.72 , which is acceptable (Mather M. Paul, 2004).

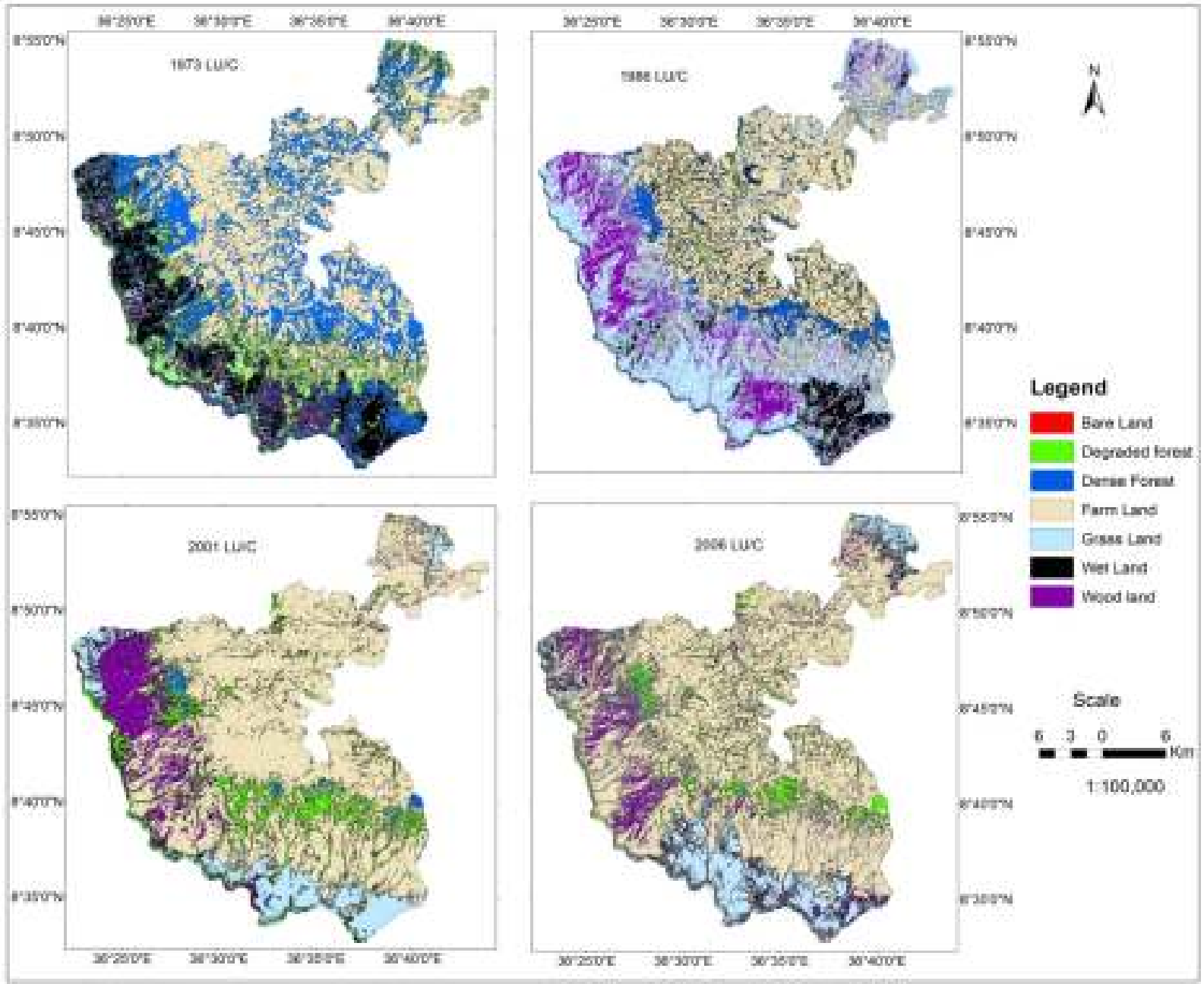

Figure 3: Land use/land cover map of Jima Arjo at different years

\section{Land Use/ Land Cover Change Assessment}

In the study area, the temporal and areal dynamics of various land use/land cover categories across 1973 2006 have been analyzed. Analyzing the change at different times, help in determining the causal factors, the level of the change and the respective management techniques. For this purpose, the whole time range has been segmented into three periods (1973 - 1986, 1986 2001 and 2001 - 2006) and finally the overall change (1973 - 2006) has been assessed.

\section{LU/LC Change between 1973 to 1986}

Between 1973 and 1986 (table 2), open wood land and dense forest land showed maximum changes; while the first one increased with $140.12 \mathrm{~km}^{2}\left(10.77 \mathrm{~km}^{2} / \mathrm{yr}\right.$ mean rate); the later one decreased with $112.6 \mathrm{~km}^{2}(8.66$ $\mathrm{km}^{2} / \mathrm{yr}$ ). Degraded forest and grassland also showed significant changes in that the earlier one has decreased with $85.02 \mathrm{~km}^{2}\left(6.34 \mathrm{~km}^{2} / \mathrm{yr}\right)$ but the later one has expanded with $76.59 \mathrm{~km}^{2}$ (with rate of $5.89 \mathrm{~km}^{2} / \mathrm{yr}$ ). Wet land has also reduced with $27.17 \mathrm{~km}^{2}$ but bare land showed some degree of expansion. Agricultural land in this period showed some expansion $\left(1.55 \mathrm{~km}^{2}\right)$ and the rate of expansion over the period has been estimated as $0.1 \mathrm{~km}^{2} / \mathrm{yr}$.

The data of the change detection matrix (table 3) clearly indicates the trend of each land category in this period. Farm land which was the largest land category (over $43 \%$ ) over the period has not shown significant change owing to loose and gain of an area. While it gained $69.55 \mathrm{~km}^{2}$ areas mostly from dense forest $\left(48.94 \mathrm{Km}^{2}\right)$; it lost $67.06 \mathrm{~km}^{2}$ area to other land category (mainly to open woodland and grassland). Insignificant portion of the farm land $\left(0.28 \mathrm{~km}^{2}\right)$ was converted in to dense forest due to some forest reestablishment. 
Table 2: Extent of land use/cover change in 1973 and 1986 years

\begin{tabular}{lcccccc}
\hline \multirow{2}{*}{ LU/LC Category } & \multicolumn{2}{c}{$\mathbf{1 9 8 6}$} & \multicolumn{2}{c}{$\mathbf{1 9 7 3}$} & $\begin{array}{c}\text { Change } \\
\mathbf{( k m}^{\mathbf{2}} \mathbf{)}\end{array}$ & $\begin{array}{c}\text { Average Rate of } \\
\text { Change } \mathbf{( k m}^{\mathbf{2}} \mathbf{)}\end{array}$ \\
\cline { 2 - 6 } & $\left.\mathbf{A r e a} \mathbf{( k m}^{\mathbf{2}}\right)$ & $\mathbf{\%}$ & $\left.\mathbf{A r e a} \mathbf{( k m}^{\mathbf{2}}\right)$ & $\mathbf{\%}$ & 1.55 & 0.1 \\
Farm Land & 338.41 & 43.8 & 336.86 & 43.62 & -112.6 & -8.66 \\
Dense Forest & 66.797 & 8.6 & 179.38 & 23.2 & -11.6 & -6.34 \\
Degraded Forest & 22.49 & 2.9 & 107.51 & 13.64 & -85.02 & 5.89 \\
Grass Land & 108.25 & 14.1 & 31.66 & 4.113 & 76.59 & 10.78 \\
Open Wood Land & 175.27 & 22.7 & 35.15 & 4.524 & 140.12 & -2.09 \\
Wet Land & 57.33 & 7.4 & 84.5 & 10.9 & -27.17 & 0.3 \\
Bare Land & 4.01 & 0.5 & 0.3 & 0.003 & 3.71 & \\
Total Area & 772.5 & 100 & 772.5 & 100 & & \\
\hline
\end{tabular}

Table 3: Land use/cover change matrix of 1973 and 1986 years image data

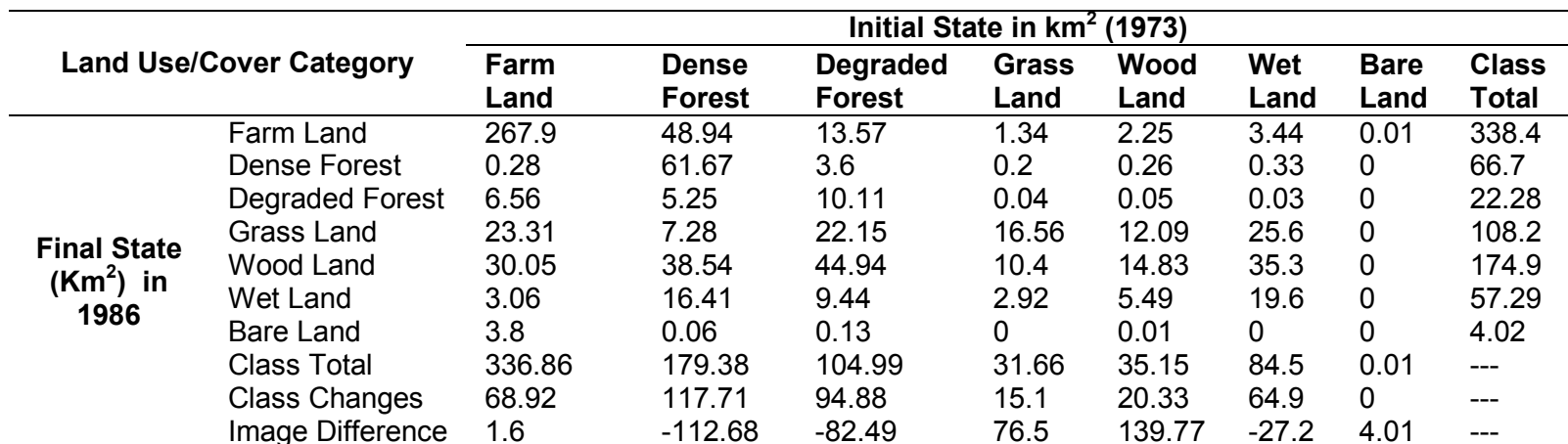

Note: The numbers in the row class total indicate the initial state whereas that of the column indicate the final state of a given land use/ land cover type in $\mathrm{Km}^{2}$. The Diagonals indicate areas that remained unchanged.

Dense forest, in addition to its conversion to farm land, has been transformed into open woodland and thus has shown significant reduction (about $112.7 \mathrm{~km}^{2}$ ). Yet, some of the dense forestland at the initial period were abandoned and transformed to grassland and degraded forest land. Of the original $104.99 \mathrm{~km}^{2}$ area of degraded forest land, only $10.11 \mathrm{~km}^{2}$ area has been left unchanged during the final state. Apart from its transformation to farmland, it has been converted to open wood land, grass land and partly to others. Although, the grassland category expanded over the period, some of it has been transformed and gave rise to the revival of some woody trees and others. The open woodland, owing to its less contribution to transformation/conversion but the conversion of others to it, increased in size more than the other categories. Much of the initial state of the wetland has also been converted to open wood land and grass land and hence declined in size at the final period. Comparatively, the bare land though has least areal converge over the period, has increased in extent.

\section{LU/LC Change between 1986 to 2001}

This period clearly showed the massive land transformation and magnified the state of human intervention in an ecosystem. With more or less equal time interval with that of 1973 to 1986 period, the amount of farm land during 1986 to 2001 , has increased extremely (increased with $151.715 \mathrm{~km}^{2}$ as compared to $1.55 \mathrm{~km}^{2}$ in the previous period) with $10.11 \mathrm{~km}^{2} / \mathrm{yr}$ average rate of change. Large patches of native vegetations have been removed, degraded and either converted or transformed in to farm land. Dense forest has shrunk to the level of inexistence being pushed by the expanding agricultural frontier and other forest product consumption. It constituted only $10.734 \mathrm{~km}^{2}$ in $2001(1.4 \%$ of the district's total area). Degraded forest area has expanded over the period. The original grass lands, open wood lands and wet lands were drastically diminished. Bare land showed expansion over the period (table 4).

The table of matrix (table 5) shows that farmland (with over $63 \%$ coverage), has expanded through out the period due to largely the conversion of the initial open wood land $\left(74.49 \mathrm{Km}^{2}\right)$ followed by grass land $\left(47.97 \mathrm{Km}^{2}\right)$. Farmland also extended to dense forestland (with $32.27 \mathrm{~km}^{2}$ ). Some of the previously wet lands and degraded forests were also converted to farm lands at the final state of the period. Dense forest was radically diminished more than grassland. It was degraded (16.19 $\mathrm{Km}^{2}$ ) and transformed to open wood land and grass land. The degraded forest land also showed relative increment in size during the period.

Table 4: Extent of land use/cover in 1986 and 2001 years

\begin{tabular}{|c|c|c|c|c|c|c|}
\hline \multirow{2}{*}{ LU/LC Category } & \multicolumn{2}{|c|}{2001} & \multicolumn{2}{|c|}{1986} & \multirow{2}{*}{$\begin{array}{c}\begin{array}{c}\text { Change } \\
\left(\mathrm{km}^{2}\right)\end{array} \\
\end{array}$} & \multirow{2}{*}{$\begin{array}{c}\text { Rate of Change } \\
\left(\mathrm{km}^{2} / \mathrm{yr}\right)\end{array}$} \\
\hline & Area $\left(\mathrm{km}^{2}\right)$ & $\%$ & Area $\left(\mathrm{km}^{2}\right)$ & $\%$ & & \\
\hline Farm Land & 490.126 & 63.4 & 338.411 & 43.8 & 151.715 & 10.11 \\
\hline Dense Forest & 10.734 & 1.4 & 66.797 & 8.6 & -65.397 & -3.74 \\
\hline Degraded Forest & 62.344 & 8.1 & 22.493 & 2.9 & 39.851 & 2.66 \\
\hline Grass Land & 95.586 & 12.4 & 108.253 & 14.1 & 12.667 & -0.84 \\
\hline Open Wood Land & 103.403 & 13.4 & 175.275 & 22.7 & -71.872 & -4.79 \\
\hline Wet Land & 2.688 & 0.3 & 57.335 & 7.4 & -54.647 & -3.64 \\
\hline Bare Land & 7.699 & 1 & 4.02 & 0.5 & 3.679 & 0.24 \\
\hline Total Area & 772.5 & 100 & 772.5 & 100 & & \\
\hline
\end{tabular}


Table 1: Land use/cover change matrix of 1986 and 2001 years image data

\begin{tabular}{|c|c|c|c|c|c|c|c|c|c|}
\hline \multirow{2}{*}{\multicolumn{2}{|c|}{$\begin{array}{l}\text { Land Use/Land Cover } \\
\text { Category }\end{array}$}} & \multicolumn{8}{|c|}{ Initial State in $\mathrm{Km}^{2}(1986)$} \\
\hline & & $\begin{array}{l}\text { Farm } \\
\text { Land }\end{array}$ & $\begin{array}{l}\text { Dense } \\
\text { Forest }\end{array}$ & $\begin{array}{c}\text { Degraded } \\
\text { Forest }\end{array}$ & $\begin{array}{l}\text { Grass } \\
\text { Land }\end{array}$ & $\begin{array}{l}\text { Wood } \\
\text { Land }\end{array}$ & Wet Land & $\begin{array}{l}\text { Bare } \\
\text { Land }\end{array}$ & $\begin{array}{l}\text { Class } \\
\text { Total }\end{array}$ \\
\hline \multirow{10}{*}{ 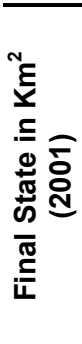 } & Farm Land & 301.21 & 32.27 & 7.94 & 47.97 & 74.49 & 23.57 & 3.49 & 490.06 \\
\hline & Dense Forest & 0 & 6.08 & 0.16 & 0.92 & 2.62 & 0.3 & 0.02 & 10.73 \\
\hline & Degraded Forest & 8.67 & 16.19 & 11.98 & 13.29 & 9.87 & 1.2 & 0.24 & 62.34 \\
\hline & Grass Land & 16.22 & 2.18 & 0.29 & 29.5 & 27.64 & 19.3 & 0.03 & 95.53 \\
\hline & Open Wood Land & 6.59 & 6.63 & 0.94 & 16.31 & 59.21 & 11.61 & 0.08 & 103.38 \\
\hline & Wet Land & 0.28 & 0.12 & 0.02 & 0.75 & 0.82 & 0.57 & 0 & 2.69 \\
\hline & Bare Land & 5.86 & 0.69 & 0.17 & 0.26 & 0.73 & 0.08 & 0.03 & 7.7 \\
\hline & Class Total & 338.4 & 66.8 & 22.49 & 108.25 & 175.23 & 57.33 & 4.02 & --- \\
\hline & Class Changes & 37.16 & 60.72 & 10.51 & 81.44 & 116.02 & 56.75 & 3.99 & --- \\
\hline & Image Difference & 151.65 & -56.06 & 39.85 & -12.47 & -71.85 & -54.64 & 3.68 & --- \\
\hline
\end{tabular}

\section{LU/LC Change between 2001 to 2006}

This period covers relatively the shortest time range. During the period, farms were still expanding (raised by $17.3 \%)$ at the expense of open woodland and grassland which were diminished with 11.91 and $18.94 \mathrm{~km}^{2}$, respectively. Inaccessible areas that were previously covered with woodland and grasslands seem the next target for conversion. Wet lands were also became irrigable farms in the period. Degraded forest land was increased owing to the removal of the dense forest over the area. Some of the bare lands in the area that seem to rehabilitate were reused for farming $\left(0.02 \mathrm{~km}^{2}\right)$. Degraded trees and grasses were begun to emerge during the final state over some of the bare lands at the initial state (Table 6 and 7).

Table 6: Extent of land use/cover in 1986 and 2001 years

\begin{tabular}{|c|c|c|c|c|c|c|}
\hline \multirow{2}{*}{ LU/LC Category } & \multicolumn{2}{|c|}{2006} & \multicolumn{2}{|c|}{2001} & \multirow{2}{*}{$\begin{array}{c}\text { Change } \\
\left(\mathrm{km}^{2}\right)\end{array}$} & \multirow{2}{*}{$\begin{array}{c}\text { Rate of Change } \\
\left(\mathrm{km}^{2} / \mathrm{yr}\right)\end{array}$} \\
\hline & Area $\left(\mathrm{km}^{2}\right)$ & $\%$ & Area $\left(\mathrm{km}^{2}\right)$ & $\%$ & & \\
\hline Farm Land & 507.4 & 65.7 & 490.1 & 63.4 & 17.3 & 3.46 \\
\hline Dense Forest & 8.19 & 1.1 & 10.7 & 1.4 & -2.51 & -0.502 \\
\hline Degraded Forest & 87.68 & 11.35 & 62.34 & 8.1 & 25.34 & 5.068 \\
\hline Grass Land & 83.67 & 10.83 & 95.58 & 12.4 & -11.91 & -2.382 \\
\hline Open Wood Land & 84.46 & 10.9 & 103.4 & 13.4 & -18.94 & -3.788 \\
\hline Wet Land & 0.84 & 0.12 & 2.688 & 0.3 & -1.848 & -0.37 \\
\hline Bare Land & 0.23 & 0.03 & 7.691 & 1 & -7.461 & -1.5 \\
\hline Total Area & 772.5 & 100 & 772.5 & 100 & & \\
\hline
\end{tabular}

Table 7: Land use/cover change matrix of 2001 and 2006 years image data

\begin{tabular}{|c|c|c|c|c|c|c|c|c|c|}
\hline \multirow{2}{*}{\multicolumn{2}{|c|}{$\begin{array}{c}\text { Land Use/Land Cover } \\
\text { Category }\end{array}$}} & \multicolumn{8}{|c|}{ Initial Status in Sq. Km (2001) } \\
\hline & & Farm & $\begin{array}{l}\text { Dense } \\
\text { Forest }\end{array}$ & $\begin{array}{c}\text { Degraded } \\
\text { Forest }\end{array}$ & Grass & Wood & Wet & $\begin{array}{l}\text { Bare } \\
\text { Land }\end{array}$ & $\begin{array}{l}\text { Class } \\
\text { Total }\end{array}$ \\
\hline \multirow{10}{*}{ 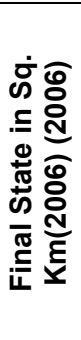 } & Farm Land & 456 & 0.43 & 5.07 & 39.9 & 3.95 & 2.02 & 0.1 & 507.47 \\
\hline & Dense Forest & 0 & 7.01 & 0.36 & 0.62 & 0.06 & 0.1 & 0.04 & 8.19 \\
\hline & Degraded Forest & 0.02 & 0.73 & 53.76 & 0.01 & 32.09 & 0.02 & 0.97 & 87.6 \\
\hline & Grass Land & 20.01 & 0.23 & 0.06 & 44.94 & 15.8 & 0.14 & 2.47 & 83.65 \\
\hline & Woodland & 14.01 & 2.12 & 2.89 & 9.96 & 51.48 & 0.01 & 3.92 & 84.39 \\
\hline & wet Land & 0 & 0.21 & 0.2 & 0.03 & 0 & 0.4 & 0 & 0.84 \\
\hline & Bare Land & 0.02 & 0 & 0.01 & 0.07 & 0.01 & 0 & 0.1 & 0.21 \\
\hline & Class Total & 490.1 & 10.73 & 62.35 & 95.53 & 103.39 & 2.69 & 7.6 & \\
\hline & Class Changes & 34.06 & 0.72 & 8.59 & 50.59 & 51.91 & 2.29 & 7.5 & \\
\hline & Image Difference & 17.41 & -2.54 & 25.25 & -11.88 & -19 & -1.85 & -7.39 & \\
\hline
\end{tabular}

\section{LU/LC Change between 1973 to 2006}

Considering the overall study period, a remarkable increase in the areal extent of farm land has been evident; from $336.86 \mathrm{~km}^{2}(43.6 \%)$ in 1973 to $507.4 \mathrm{~km}^{2}(65.7 \%)$ in 2006 with $170.54 \mathrm{~km}^{2}$ variation across 33 years. While grass land and wood land showed relative increment in coverage, other vegetation categories (particularly dense forest) were dropped down and $171.16 \mathrm{~km}^{2}$ of the original forestland cover now devoid of forest with an average loss of $5.186 \mathrm{~km}^{2}$ per annum. Of the initial above $23 \%$ of dense forest cover, only $1.1 \%$ of the area possessed the original forest. Wet land also reduced and almost reached the status of inexistence were only $0.12 \%$ of the original $10.93 \%$ remained (Table 8 ).

Table 8: Statistical Summary of land use/land cover from 1973 - 2006

\begin{tabular}{lcccccc}
\hline \multirow{2}{*}{ LU/LC Category } & \multicolumn{2}{c}{$\mathbf{2 0 0 6}$} & \multicolumn{2}{c}{$\mathbf{1 9 7 3}$} & $\begin{array}{c}\text { Change } \\
\text { (Sq.Km) }\end{array}$ & $\begin{array}{c}\text { Rate of Change } \\
\text { (Sq.Km/yr) }\end{array}$ \\
\cline { 2 - 5 } & Area $\mathbf{K m}^{\mathbf{2}} \mathbf{)}$ & $\mathbf{\%}$ & $\mathbf{A r e a}\left(\mathbf{K m}^{\mathbf{2}} \mathbf{)}\right.$ & $\mathbf{\%}$ & 170.54 & 5.168 \\
Farm Land & 507.4 & 65.7 & 336.86 & 43.61 & -17.16 & -186 \\
Dense Forest & 8.19 & 1.1 & 179.35 & 23.21 & -171.16 & -0.52 \\
Degraded Forest & 87.68 & 11.35 & 104.96 & 13.6 & -17.28 & 1.576 \\
Grass Land & 83.67 & 10.8 & 31.66 & 4.1 & 52.01 & 1.5 \\
Wood Land & 84.46 & 10.9 & 35.15 & 4.55 & 49.31 & -2.54 \\
Wet Land & 0.84 & 0.12 & 84.52 & 10.93 & -83.68 & 0.01 \\
Bare Land & 0.23 & 0.03 & 0.01 & 0.001 & 0.22 & \\
Total Area & $\mathbf{7 7 2 . 5}$ & $\mathbf{1 0 0}$ & $\mathbf{7 7 2 . 5}$ & $\mathbf{1 0 0}$ & & \\
\hline
\end{tabular}


Muleta Ebissa Feyissa

Table 9 showed how much the land use/land cover of the area is dynamic. It clearly indicates the ultimate impact of extreme anthropogenic interventions in accelerating the removal of the original ecosystem over
Sci. Technol. Arts Res. J., Jan-March 2015, 4(1): 139-148

the area. This is evident in that farm land has been increased dramatically; the forestlands and wetlands were declined extremely over the years.

Table 9: Summary of land use/cover change matrix of 1973 and 2001 years image data

\begin{tabular}{|c|c|c|c|c|c|c|c|c|c|}
\hline \multirow{2}{*}{\multicolumn{2}{|c|}{$\begin{array}{c}\text { Land Use/Land Cover } \\
\text { Category }\end{array}$}} & \multicolumn{8}{|c|}{ Initial State Sq. Km (1973) } \\
\hline & & $\begin{array}{l}\text { Farm } \\
\text { land }\end{array}$ & $\begin{array}{l}\text { Dense } \\
\text { Forest }\end{array}$ & $\begin{array}{l}\text { Degraded } \\
\text { Forest }\end{array}$ & $\begin{array}{l}\text { Grass } \\
\text { land }\end{array}$ & $\begin{array}{l}\text { Wood } \\
\text { Land }\end{array}$ & $\begin{array}{l}\text { wet } \\
\text { Land }\end{array}$ & $\begin{array}{l}\text { Bare } \\
\text { Land }\end{array}$ & $\begin{array}{l}\text { Class } \\
\text { Total }\end{array}$ \\
\hline \multirow{10}{*}{ 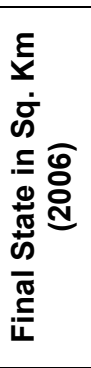 } & Farmland & 313.87 & 65.1 & 73.89 & 14.58 & 8.01 & 31.99 & 0 & 507.4 \\
\hline & Dense Forest & 0.16 & 7.77 & 0.13 & 0.01 & 0.02 & 0.1 & 0 & 8.19 \\
\hline & Degr. Forest & 0.86 & 60.14 & 24.9 & 0.59 & 0.81 & 0.38 & 0 & 87.68 \\
\hline & Grassland & 21.35 & 15.41 & 0.97 & 7.06 & 6.3 & 32.58 & 0 & 83.67 \\
\hline & Woodland & 0.45 & 30.92 & 4.99 & 9.4 & 19.95 & 18.75 & 0 & 84.46 \\
\hline & Wetland & 0.01 & 0.01 & 0.07 & 0.01 & 0.03 & 0.71 & 0 & 0.84 \\
\hline & Bareland & 0.16 & 0 & 0.01 & 0.01 & 0.03 & 0.01 & 0.01 & 0.23 \\
\hline & Class Total & 336.86 & 179.35 & 104.96 & 31.66 & 35.15 & 84.52 & 0.01 & \\
\hline & Class Changes & 22.99 & 171.58 & 80.06 & 24.6 & 15.2 & 83.81 & 0 & \\
\hline & Image Difference & 170.58 & -171.2 & -17.28 & 52.01 & 49.31 & -83.68 & 0.22 & \\
\hline
\end{tabular}

\section{Land Use/Cover Distribution Across Slope}

The pattern of land use/cover correlates to a great extent with the slope of a given area. Agriculture is perhaps one of the activities that largely depend on slope especially in areas where rainfall is intense. Expansion of agriculture over steep slopes results in a disastrous effect towards soil resources. Towards this analysis, the slope derived from SRTM data has been reclassified into 4 slope categories $\left(<5^{0}, 5-12^{0}, 12-25^{\circ}\right.$ and above $\left.25^{\circ}\right)$ and the land use/cover classes of the initial (1973) and the final (2006) images in each slope category has been tabulated in ArcGIS environment for comparison (table 10).

Table 10: Land Class Extent (in $\mathrm{km}^{2}$ ) across Each Slope Category at the Initial and Final States

\begin{tabular}{|c|c|c|c|c|c|c|c|c|}
\hline \multirow{2}{*}{$\begin{array}{l}\text { LU/LC } \\
\text { Categories }\end{array}$} & \multicolumn{2}{|c|}{$<5^{\circ}$} & \multicolumn{2}{|c|}{$5^{0}-12^{0}$} & \multicolumn{2}{|c|}{$12^{0}-25^{0}$} & \multicolumn{2}{|c|}{$>25^{\circ}$} \\
\hline & 1973 & 2006 & 1973 & 2006 & 1973 & 2006 & 1973 & 2006 \\
\hline Farm Land & 84.8 & 158.9 & 171.7 & 233.6 & 74.8 & 105.9 & 5.5 & 8.91 \\
\hline Dense Forest & 46.2 & 0.1 & 61.9 & 1.3 & 64.4 & 5.7 & 6.9 & 0.97 \\
\hline Degraded forest & 44.4 & 22.6 & 41.9 & 31.7 & 17.8 & 31.8 & 0.8 & 1.56 \\
\hline Wood land & 23.9 & 21.1 & 7.5 & 33.5 & 3.8 & 28 & 0.2 & 1.8 \\
\hline Grass Land & 22.8 & 68.5 & 5.8 & 8.2 & 2.9 & 6.1 & 0.05 & 0.78 \\
\hline Wet Land & 49.9 & 0.8 & 20.1 & 0 & 13.8 & 0 & 0.65 & 0 \\
\hline Bare Land & 0 & 0.05 & 0.008 & 0.14 & 0 & 0.041 & 0 & 0 \\
\hline Total Area $\left(\mathrm{km}^{2}\right)$ & 272.1 & & 308.5 & & 177.8 & & 14.12 & \\
\hline Percentage & 35.2 & & 39.9 & & 23 & & 1.8 & \\
\hline
\end{tabular}

It shows that in 1973, though, farmland occupied wider areas (31.2\% area), almost all land use/ cover types were evident in the gentler slope with $<5^{\circ}$. In $2006,58.4 \%$ of the slope $<5^{0}$ became farmland. It means that the previous un-accessed areas with gentler slope now accessed and transformed in to farmlands. Dense forestland covered $46.2 \mathrm{~km}^{2}$ of the area at the beginning within this slope category. But only $0.1 \mathrm{~km}^{2}$ has been left in 2006. Degraded forests in this slope range were also reduced by half. In addition, the previous wetlands evident on gentler slope were almost disappeared. On the other hand, grass lands were revived and hence increased in areal extent in 2006.

The slope class moderate to sloppy $\left(5^{0}-12^{0}\right)$ possesses more area of Jima Arjo (39.9\%) and it is in this category that farming has its maximum share in coverage and expansion level in both years (1973 and 2006). In this slope range dense forest loss was extreme. More than $60 \mathrm{~km}^{2}$ area of dense forest removed or converted in to farmlands, woodland or others.

Sloppy to steep slope $\left(12^{0}-25^{0}\right)$ areas were still where farmland is dominant. It is in this slope category that forest land is relatively has more concentration in both years though $58.7 \mathrm{~km}^{2}$ faced loss/conversion.
Strongly steep slope $\left(>25^{\circ}\right)$ covering about $14.12 \mathrm{~km}^{2}$ of the area. Farmland with $5.5 \mathrm{~km}^{2}$ being concentrated at $25^{\circ}$ at the beginning was extended in areal cover in 2006 to extremely steep slope in the district. Forestland removal/conversion is also evident across this slope.

In general, the data showed that over the fragile steep slopes $\left(>12^{0}\right)$ that should have been kept for either tree crop production or forest land, farming has become dominant. The remaining forest land (both the dense forest and degraded forest) which has been concentrated more in this slope category were likely to be under greater threat.

\section{Land Use/Cover Change Vulnerability Assessment and Mapping}

In order to address the state of land use/land cover change and its future trend, the identification of prone areas is of vital importance. In this study the future vulnerable areas to change has been studied through determining the factors of change.

\section{Generation of Land Use/Land Cover Change Factors Data}

Land cover change is primarily determined by anthropogenic factors. The more a land cover is suitable 


\section{Muleta Ebissa Feyissa}

and proximity for use, the more susceptible it is to change and degradation. Altitude and slope, accessibility and proximity to settlement and rivers are among the determining factors that can determines land cover change (Wright, 1993; Mannion, 2002 and Eastman J. Ronald et al., 2005). In addition, soil is the other factor that determines land cover change (Mesfin, 1998). Troeh, et al., (1980) also considered land cover types by themselves determine land susceptibility to change.

Accordingly, the study considered the 2006 year land cover type, factors of accessibility, proximity to settlement,
Sci. Technol. Arts Res. J., Jan-March 2015, 4(1): 139-148

proximity to rivers, slope, soil type and agroclimate of the area. The integration of multi factors and criterion were found to be significant (Hey Wood lan, et al., 2002) and hence achieved through multi-criteria evaluation techniques in GIS.

For the study, the identified factors and criterion of change were weighted and scored based on their contribution. Reclassification of each factor has been made by assigning scale values ranging from $1-7$ (since the maximum class category is the land use/cover class).

Table 11: Factors of land use/cover change scale values and their associated weight

\begin{tabular}{|c|c|c|c|c|c|c|c|c|}
\hline \multirow{2}{*}{ Factors } & \multicolumn{7}{|c|}{ Assigned Scale Values } & \multirow{2}{*}{ Weight } \\
\hline & 7 & 6 & 5 & 4 & 3 & 2 & 1 & \\
\hline Land Cover Type & Forest & Dg. Forest & Woodl & Grassl & Wet Land & Farml & Barel & 0.1733 \\
\hline Soil Type & Nitisols & Vertisols & Gleysols & Acrisol & -- & -- & -- & 0.0551 \\
\hline Agro-Climate Type & $\begin{array}{l}\text { Wet Sub- } \\
\text { tropics }\end{array}$ & $\begin{array}{l}\text { Wet } \\
\text { Tropics }\end{array}$ & $\begin{array}{l}\text { Wet } \\
\text { Temprate }\end{array}$ & -- & -- & -- & -- & 0.0559 \\
\hline Slope Range (Degree) & $<2$ & $2-5$ & $5-10$ & $10-16$ & $16-25$ & 25-35 & $>35$ & 0.1947 \\
\hline Dist.All Weather Road(Km) & $<2$ & $2-5$ & $5-8$ & $8-12$ & $12-16$ & $16-22$ & $>22$ & 0.1460 \\
\hline Dis.Dry Weather Road(Km) & $<1$ & $1-3$ & $3-6$ & $6-10$ & $10-15$ & $15-22$ & $>22$ & 0.1127 \\
\hline Distance to Foot Path(Km) & $<1$ & $1-3$ & $3-5$ & $5-7$ & $7-10$ & $10-15$ & $>15$ & 0.0856 \\
\hline Distance to Town (Km) & $<3$ & $3-6$ & $6-10$ & $10-15$ & $15-21$ & $21-27$ & $>27$ & 0.0854 \\
\hline Distance to Rivers (Km) & $>9$ & $6-9$ & $4-6$ & $2-4$ & $1-2$ & $0.5-1$ & $<0.5$ & 0.0912 \\
\hline
\end{tabular}

Since weight evaluation for more factors at a time is quite difficult, pairwise comparison method has proven capability in comparing the relative importance of criterion at a time (Eastman J. Ronald, 2002 and Hey Wood lan et al., 2002). Hence, in identifying vulnerable areas, pairwaise comparison has been made using IDRISI Selva software. Reclassifying the data layers, the weight of each layer factor has been assigned (table 11) and the layer factors were produced (Figure 4).

Based on the assigned weighted values, pair wise comparison has been made among each of the factor layers in the IDRISI Selva version 17 GIS decision support system in identifying vulnerable areas. Weighted overlay has been implemented to the factors (eq. 2) in the ArcGIS 10.2 software spatial analyst raster calculator (Figure 5).

Susceptibility to Change $=\mathrm{LU} / \mathrm{LC}^{*} 0.1733+$ Agro-Climate * $0.0559+$ Slope ${ }^{*} 0.1947+$ Soil type ${ }^{*} 0.0551$ +Distance from All Weather Roads * $0.1460+$ Distance from Dry Weather Roads * 0.1127 + Distance from Foot Paths * $0.0856+$ Distance to Towns*0.0854+ Proximity to Rivers* 0.0912

$$
\text { Equation (2) }
$$

Figure 5 clearly gives visual impression and shows the level (Low Moderate High and Extreme) and areas vulnerable to change with the existing factors. Areas surrounding Arjo town, parts of Jamo Giros, Jarso Kamisa Bera, Hara Keku,Wayu Kiltu, Tibe Kusaye, Lalo and north-eastern parts of Hera farm associations were found within extremely to highly vulnerable range for change owing to the extreme probability of the function of the driving factors. The recently settled areas of Bedasa Didessa and Lugema, parts of Hine, the low flat laying Didessa proposed for sugarcane production were identified as highly susceptible for land use/cover transformation. The rest areas of the district fall in the range of moderate to low level of vulnerability to change/transformation.

From the whole area of the district (table 12), 5.84\% has low vulnerability to change. This includes steep slopes, inaccessible areas and areas with high probability for flooding such as Didessa river bank.

Much of the area (47.94\%) is moderately vulnerable, about $43 \%$ is highly vulnerable and about $3 \%$ is extremely vulnerable to change.

Although, farmland is not in the extremely vulnerability category, it will be vulnerable to change owing to transformation and loss of or gaining of area/areas from other cover forms. Among the vegetation categories in the area, dense and degraded forest lies within high to extreme vulnerability to change. Wood land is highly vulnerable and grass land is moderately vulnerable to change. A substantial extent of wetlands falls within moderate to high level vulnerability to change.

Table 12: Levels and extent of land use/cover change vulnerability prediction $\left(\mathrm{km}^{2}\right)$

\begin{tabular}{llllll}
\hline \multirow{2}{*}{ LU/C } & \multicolumn{4}{l}{ Level and Areal Extent of Vulnerability to change } & \multirow{2}{*}{ Total Area } \\
\cline { 2 - 5 } & Low & Moderate & High & Extreme & 507.3696 \\
Farm Land & 38.9 & 266.7 & 196.9 & 4.8 & 8.4712 \\
Dense Forest & 0 & 0.82 & 4.9 & 2.7 & 87.7064 \\
Degraded forest & 0 & 9.3 & 62.76 & 15.6 & 84.354 \\
Wood land & 0.05 & 22.2 & 61.3 & 0.82 & 83.6712 \\
Grass Land & 5.8 & 70.7 & 7.2 & 0 & 0.818 \\
Wet Land & 0.22 & 0.45 & 0.15 & 0 & 0.2304 \\
Bare Land & 0.1 & 0.13 & 0 & 0 & $\mathbf{7 7 2 . 5}$ \\
\hline Total & $\mathbf{4 5 . 0 7}$ & $\mathbf{3 7 0 . 3}$ & $\mathbf{3 3 3 . 2 1}$ & $\mathbf{2 3 . 9 2}$ & $\mathbf{1 0 0}$ \\
\% & $\mathbf{5 . 8 4}$ & $\mathbf{4 7 . 9 4}$ & $\mathbf{4 3 . 1 2}$ & $\mathbf{3 . 1}$ & \\
\hline
\end{tabular}




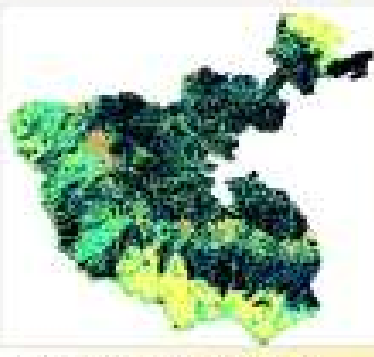

Land UsovCaver Category
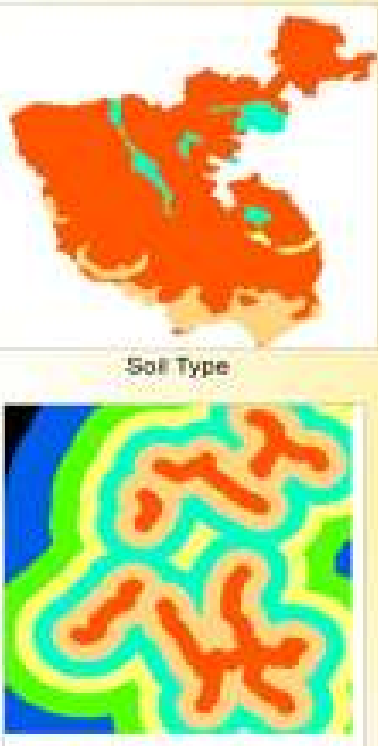

Distance to Foot Patis

\section{Reclassified Layers of Change Factors}

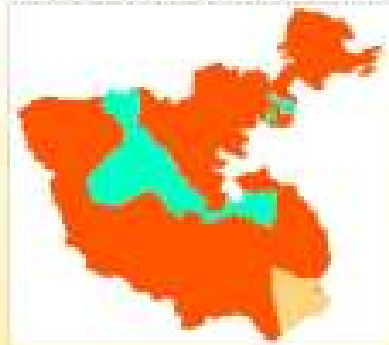

Agre Clmate Canogory

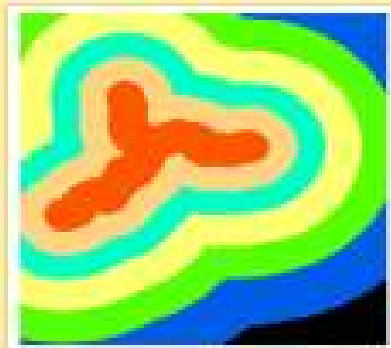

Ostance to All Westher Roads

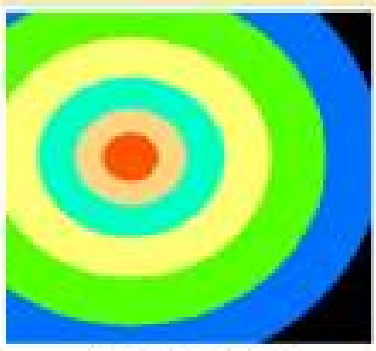

Distance to Towrs

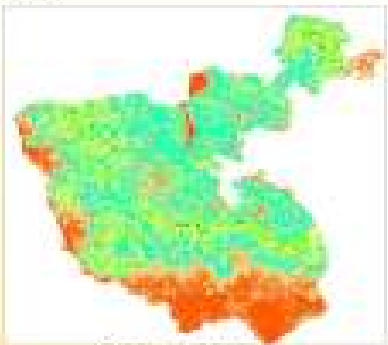

Slope Casogary

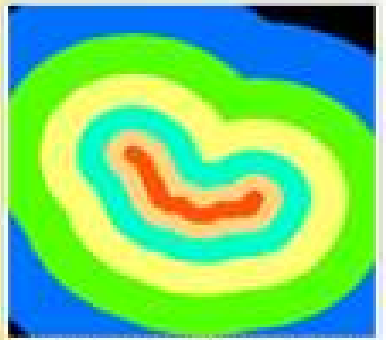

Distance to Dry Weather Roads

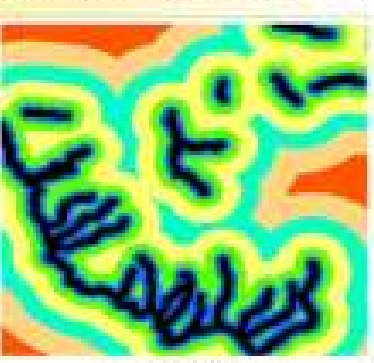

Distance is Rivers

$105^{50 a l e} \quad 10 \mathrm{Km}$

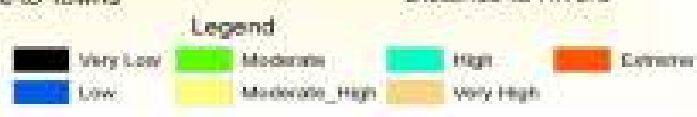

Figure 5: Map of reclassified factor layers of susceptibility to change

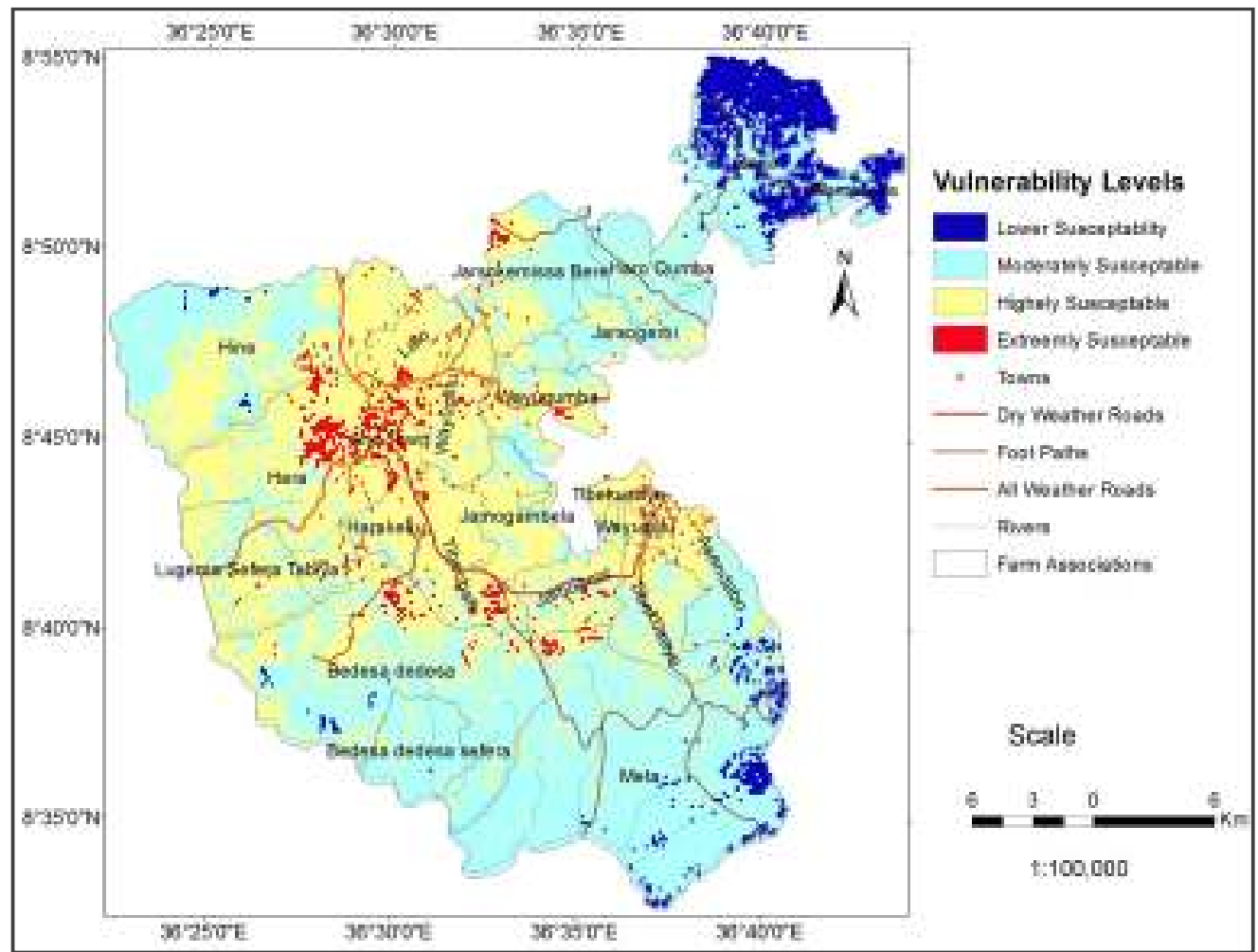

Figure 6: Map of land use/cover susceptibility to change 


\section{CONCLUSIONS}

The study revealed that a broader change and dynamics of land use/cover has been associated with broader range of impacts on the terrestrial resources of the area during 1973 to 2006 . Much of the area has been modified. Strongly steep fragile slopes $\left(>25^{0}\right)$ have been converted to intensively cultivated farmlands. Farmland showed ever expanding, climbing up steep slopes and creating pressure on the remaining vegetation. The biotic diversity and the soils of the area were made susceptible to the impacts and the subsequent degradation. Large patches of the native (natural) vegetations have been converted, modified and some of the rest which are in their natural state were made prone to threats to a degree that surprises. Areas of trees have been most dramatically altered. The original natural dense forest land covering $23.2 \%$ of the total area at the initial study period (1973) has dropped down to $1.1 \%$ at the final study period owing to conversions to farmland and giving way to derived grass lands, open wood lands and degraded forest vegetations. The degraded forest land has also been converted/modified and left with $11.35 \%$. Wetlands that are supposed to play important roles in maintaining environmental quality, sustaining livelihoods and supporting biodiversity (Turyahabwe Nelson, etal., 2013) were showed reduction in size and left with $0.12 \%$ of the original $10.93 \%$.

Recent years signified that the change was more dramatic and rapid. About $46 \%$ of the area experienced high to extreme vulnerability to change. Besides farming, the unwise use of forest and natural land resource consumption has to be blamed for the natural land resource degradation over the area.

\section{Conflict of Interest}

Conflict of interest none declared.

\section{Acknowledgements}

I thank the Horn of Africa Regional Environment Center and Network (HoA-REC/N) for providing me financial support through the Demand Driven Action Research (DDAR) program.

\section{REFERENCES}

Bedru Sherefa (2006). Remote Sensing and GIS for Land Cover/Land Use Change Detection and Analysis in the Semi Natural Ecosystems and Agricultural Landscapes of the Central Ethiopian Rift valley. Submitted for fulfillment of Doctor of Natural Science (Dr. rer.nat). Dresden, Germany. P. 60.

Botkin B. Daniel and Keller A. Edward (2005). Environmental Science: Earth as a Living Planet $\left(5^{\text {th }}\right.$ Edition); John Wiley and Sons, INC; USA

Eastman Ronald, J. (2006). IDRISI Andes Guide to GIS and Image Processing; Clark Labs, Clark University.

Eastman Ronald, J., Solorzano, A. Luis and Van Fossen E. Megane. (2005). Transition Potential Modeling for Land Cover Change; In: Maguire J. David, Batty Michael, Goodchildhood F. Michael; GIS, Spatial Analysis and Modelling, Esri, USA.

Hey wood lan., Cornelius Sarah and Steve Carver (2002). An Introduction to Geographical information System, Pearson Education limited, UK.

Hurni Hans (1986). Guide Lines for Development Agents on Soil Conservation in Ethiopia: Community Forest and Soil Conservation Development Department, Ministry of Agriculture, Addis Ababa. Pp. 81-84.

ITT (2006). ENVI: The Remote Sensing Platform of Choice: Version 4.3 User's Guide; ITT Industries, Inc., USA

Krauer Jurg (1988). Rainfall Erosivity and Isoerodent Map of Ethiopia: Soil Conservation Research Project Report 15; University of Berne, Switzerland. Pp. 1-63.

Lillesand, M.T. and Kiefer W.R. (2000). Remote Sensing and Image Interpretation ( $4^{\text {th }}$ ed.), John Wiley \&Sons, Inc, New York, USA.

Lillesand M. Thomas., Kiefer W. Ralph and Chipman W. Jonathan. (2004). Remote Sensing and Image Interpretation $5^{\text {th }}$ Edi), John Wiley \& Sons, Inc., USA.

Mannion, M.A. (2002). Dynamic World, Land Cover and Land Use Change, Arnold, London.

Mather M. Paul (2004), Computer Processing of Remotely-Sensed Images, An Introduction, $\left(3^{\text {rd }}\right.$ Edition), John Wiley \& Sons Ltd, England.

Mesfin Abebe (1998). Nature and Management of Ethiopian soils; Alemaya University of Agriculture, Ethiopia.

Meyer B. William and Turner II L.B. (1998). Global land Use and Land Cover Change: An Over View. In: Meyer B. William and Turner II L.B. (ed), Changes in Land Use and Land Cover: A Global Perspective, Cambridge University Press, United Kingdom.

Ministry of Agriculture \& Rural Development of Ethiopia, Regional Land Management and World Agro forestry Center (2005). Managing Land: A Practical Guidebook for Development agents in Ethiopia; AG Printing and Publishing Ltd, Kenya. Pp. 2-14 and106-158.

Solomon Abate (1994). Land Use Dynamics, Soil Degradation and Potential for Sustainable Use in Metu Area, llubabor Region, Ethiopia. Geographica Bernensia and Geographical Society of Berne. University of Berne, Switzerland. Pp. 3-24 and 59-71.

Taffa Tulu (2002). Soil and Water Conservation for Sustainable Agriculture; Mega Publishing Enterprise, Addis Ababa. Pp. 1-6 and 36-37.

Troeh, F.R., Hobbs, J.A., and Donahue, R.L. (1980). Soil and Water conservation for productivity and environmental protection, Prentice Hall, Inc, Englewood cliffs, New Jersy.

Turyahabwe Nelson., Mwesigye David., Tumusiime., Kakuru Willy and Barasa Bernard (2013). Wetland Use/Cover Changes and Local Perceptions in Uganda Canadian Center of Science and Education 2(4).

Wall S.L., Thomas R.W., and Brown C.E. (1982). A Landsat-Based Inventory Procedure for Agriculture in California." In McDonald D. C. and Morrison D.B. (ed), Machine Processing of remotely Sensed data With Special Emphasis on Crop Inventory and Monitoring (Eighth International symposium), Purdue research Foundation, Indiana, USA.

World Bank (2006). Sustainable Land Management: Challenges, Opportunities and Trade-offs, Washington DC, USA.

Wright Lawrie (1993). Environmental Systems and Human Impact: Cambridge University Press, London. Pp. 1239. 